\title{
Research on form-focused instruction in immersion classrooms: Implications for theory and practice
}

\author{
ROY LYSTER
}

McGill University

(Received February 2004; revised July 2004)

\begin{abstract}
AB STRACT
This article presents a comparative analysis of five quasi-experimental studies involving close to I,200 students, ranging in age from 7 to I4, in 49 French immersion classrooms in Canada - a content-based instructional context where learners develop high levels of communicative ability yet demonstrate a levelling-off effect in their grammatical development. The studies investigated the effects of form-focused instruction on four areas known to be difficult for anglophone learners of French: perfect vs. imperfect past tense, conditional mood, second-person pronouns and grammatical gender. Findings suggest that effective form-focused instruction in immersion contexts, at least with respect to interlanguage features that have reached a developmental plateau, includes a balanced distribution of opportunities for noticing, language awareness and controlled practice with feedback. Less effective instructional options overemphasise negotiation for meaning in oral tasks where message comprehensibility and communication strategies circumvent the need for learners to move beyond the use of interlanguage forms.
\end{abstract}

\section{INTRODUCTION}

The extent to which knowledge gained from explicit instruction can, over time, become part of a second language (L2) learner's underlying system of implicit knowledge, and thus available for spontaneous language production, is still an open question. Some L2 acquisition theorists clearly downplay the role of explicit instruction in favour of more implicit and incidental language learning (e.g., Krashen, 1994; Long, 1996), yet reviews of empirical studies show that explicit attention to form in communicative contexts is more effective (Spada, I997; Norris and Ortega, 2000). To address these practical and theoretical issues with specific reference to learning French L2, this article aims to identify form-focused instructional options that research suggests are effective for teaching French L2, specifically in the context of Canadian French immersion classrooms.

A great deal of research pertaining to form-focused instruction in French L2 has been undertaken in the context of French immersion, which lends itself well to classroom research. Given its predominant focus on meaning, immersion 
provides a rich context for research into innovative ways of teaching and learning an L2. Immersion classrooms replicate conditions for sustained exposure and authentic communication more than most other types of $\mathrm{L} 2$ classrooms insofar as the L2 is used purposefully for the study of other subjects. In this sense, immersion provides, theoretically at least, a classroom context with optimal conditions for L2 learning. In terms of learning outcomes, research has indeed shown that immersion students develop high levels of comprehension skills as well as considerable fluency and confidence in L2 production (for overviews, see Rebuffot, I993; Swain, I997; Lyster, I999). However, these studies also point to shortcomings in grammatical accuracy that persist in immersion students' interlanguage development even after years of immersion education (Harley, Cummins, Swain and Allen, I990). Immersion education thus provides a clear example of an instructional context where focus on meaningful content leads to the development of overall communicative ability, but with linguistic gaps in terms of accuracy.

\section{THEORETICAL ORIENTATIONS}

Research in the area of form-focused instruction is of interest to both researchers and teachers, because it allows researchers to develop and test theories of L2 acquisition and yet has as a primary goal the identification of effective pedagogical practice (Ellis, 200I). Accordingly, this article aims to present an analysis of five classroom-based studies of form-focused instruction and to identify effective pedagogical options in the light of two well-known theoretical orientations: the interaction hypothesis and cognitive theory.

\section{I Interaction hypothesis}

According to Long's (I996) interaction hypothesis, conversational moves that assist interlocutors in negotiating for meaning provide learners with a primary source of target language data in ways that benefit language development. Conversational moves used to negotiate for meaning in dyadic interaction include: (a) input modifications (e.g., stress on key words, partial self-repetition); (b) semantically contingent responses (e.g., recasts, repetition); and (c) conversational modifications (e.g., confirmation checks, comprehension checks, clarification requests).

Many L2 acquisition studies have demonstrated that these conversational moves provide learners and their interlocutors with a useful set of communication strategies that facilitate comprehension (e.g., Pica, Young and Doughty, I987). However, there is still little direct evidence that conversational moves used to negotiate meaning actually drive L2 development forward by effecting changes to the underlying interlanguage system (Braidi, I995; Skehan, I998; Carroll, I999). There is also some debate concerning (a) the pedagogical feasibility and value of students using these conversational moves to negotiate meaning among themselves (Aston, I986; Foster, I998) and (b) the effectiveness of conversational moves used 
by teachers to negotiate meaning as a means of drawing their students' attention to form in classroom interaction (Lyster, I998; 2002). To negotiate meaning is to work towards 'comprehensibility of message meaning' (Pica, I994: 494). Because teachers and students are able to negotiate meaning with little or no linguistic knowledge in common, as they draw on higher-order processes involving schematic and contextual knowledge (Swain, I985; Kleifgen and Saville-Troike, I992), it remains unclear how negotiation for meaning in L2 classroom settings would suffice to drive L2 development forward effectively and efficiently.

Skehan (1998) argues that resolving communication breakdowns through negotiation for meaning entails the use of communication strategies and, as such, does not aim to effect changes in a learner's underlying interlanguage system. Pica (I994: 5I7-5I8) acknowledges that target language accuracy plays only a secondary role in negotiation, as it has been defined in L2 acquisition research: 'Negotiation, by definition, focuses on the comprehensibility of message meaning, and on the message's form only insofar as that can contribute to its comprehensibility. Learners and their interlocutors find ways to communicate messages through negotiation, but not necessarily with target-like forms' (see also Swain, I985). Thus, the interaction hypothesis is an unlikely candidate for explaining instructed L2 development, especially in classroom contexts where mutual comprehension of interlanguage forms reduces the need to negotiate for meaning.

\subsection{Cognitive theory}

A more likely candidate for explaining L2 learning in classroom settings is cognitive theory, which draws on information-processing models to describe L2 learning as the acquisition of complex cognitive skills (e.g., McLaughlin, I987; I990; Hulstijn, I990; O’Malley and Chamot, I990; Towell and Hawkins, I994; de Bot, I996; Johnson, I996; DeKeyser, I998; 200I). In cognitive theory, representation refers to the nature of items stored in memory, while processing is concerned with access to these representations.

The notion of information processing describes skill acquisition as a gradual change in knowledge from declarative to procedural mental representations (Anderson, I983; I985). Declarative knowledge is static information such as historical or geographical facts encoded in memory. Procedural knowledge is knowledge about how to do things, including the ability to apply rule-based knowledge to cognitive operations such as problem solving, as well as to motor operations such as those involved in riding a bicycle or typewriting (Anderson, I983: 2 I5). With respect to language, declarative knowledge refers to knowledge of language items, such as word definitions and rules, whereas procedural knowledge refers to knowledge about how to perform cognitive operations, such as producing language online by quickly accessing items stored in memory.

The transformation of declarative knowledge into procedural knowledge involves a transition from controlled processing, which requires a great deal of attention and use of short-term memory, to automatic processing, which operates on 
automatised procedures stored in long-term memory (Shiffrin and Schneider, I977). The transition from controlled to more automatic processing results from repeated practice in transforming declarative representations into production rules (DeKeyser, I998). The proceduralisation of rule-based declarative representations occurs through practice and feedback (Anderson, Corbett, Koedinger and Pelletier, I995), which together move learners towards a restructuring of interlanguage representations, enabling them to access a better organized representational system (McLaughlin, I990; Skehan, I998).

In the absence of feedback or other types of appropriate instructional intervention, interlanguage representations can also become automatised procedures stored in long-term memory; this explains why immersion students' grammatical development appears to plateau prematurely. Changing students' tendency to use highly accessible interlanguage forms is no small undertaking, because, once learned, 'an automatic process occurs rapidly and is difficult to suppress or alter' (McLaughlin, I987: I34). The challenge is to help learners develop new targetlike representations which can compete with the interlanguage forms (Ranta and Lyster, 2004). This necessarily requires incorporating a larger role for form-focused instruction.

\section{FORM-FOCUSED INSTRUCTION}

Form-focused instruction, according to Ellis (200I: I-2), refers to 'any planned or incidental instructional activity that is intended to induce language learners to pay attention to linguistic form.' As conceptualised in L2 acquisition research, form-focused instruction differs from decontextualised grammar lessons. The latter emphasise the learning and categorising of forms rather than relating these forms to their communicative functions and appear to have minimal effect in classrooms where learners' exposure to the L2 has been primarily message-oriented (Swain, I996). Lightbown (I998) suggests that isolated grammar lessons may have only minimal effects in these contexts because learners exposed to language 'instruction' separately from meaningful language 'use' are indeed more likely to learn to treat language instruction as separate from language use; this is called transfer-appropriate learning (Segalowitz, I997). In other words, language features learned in isolated grammar lessons may be remembered in similar contexts (e.g., during a grammar test), but hard to retrieve in the context of communicative interaction. Conversely, language features noticed during communicative interaction may be more easily retrieved in communicative contexts. Accordingly, form-focused instructional activities are generally considered most effective when embedded in communicative contexts, even though the extent to which form-focused instruction must be integrated into communicative activities is still open to debate (e.g., Lightbown, I998; Ellis, 2002). Also open to further inquiry are the differential effects of formfocused instructional options that vary in degrees of explicitness, as well as the types of L2 features that can most benefit from form-focused instruction (see Spada, I997; 
Doughty and Williams, I998; Long and Robinson, I998; Lightbown and Spada, I999; Norris and Ortega, 2000; Ellis, 200I).

Immersion contexts lend themselves particularly well to research into formfocused instruction, because they require novel ways of focusing on form in primarily experiential contexts to counter the persistence of interlanguage forms in immersion students' productive repertoire. In this regard, Swain (I988) and Harley (I993) explained that the experiential approach driving content-based language instruction effectively promotes incidental language learning, but does not necessarily enable students to acquire specific form-function relationships. Harley (I993) proposed that form-focused instruction is needed to address L2 features that: (a) differ in non-obvious or unexpected ways from the $\mathrm{LI}$; (b) are irregular, infrequent, or otherwise lacking in perceptual salience in the L2 input; (c) do not carry a heavy communicative load. In view of these criteria, Harley suggested that the following features of French may not be noticed in communicative classroom discourse by L2 learners and thus require form-focused instruction:

- distinctions in grammatical gender;

- distinctions in second-person pronouns;

- distinctions in the use of avoir and être;

- various features of the verb system such as the use of the imperfect, conditionals and third-person agreement rules;

- lexical features such as derivation (i.e., productive use of affixes) and verbs with syntactic frames incongruent with the learner's LI.

I will describe five classroom intervention studies that investigated the effects of form-focused instruction on four of these features known to be difficult for L2 learners of French: functional distinctions in the use of perfect and imperfect past tenses (passé composé vs. imparfait), the conditional mood, second-person pronouns and grammatical gender (see Table I for a comparative summary of these studies). Conducted at various grade levels $(2,5,6,7,8)$ in urban schools in or near the cities of Vancouver, Toronto and Montreal, the five studies span a period of I 5 years, from I989 to 2004, and involved almost I,200 students in about 50 French immersion classrooms. For each study, I will first explain the language learning problem before describing the pedagogical intervention and the learning outcomes.

\section{I Perfect and imperfect past tenses}

The verb system in French presents one of the most persistent problems for learners of French L2, and the passé composé and imparfait are especially challenging for anglophone learners of French, because the form-function mappings of these tenses are not clear-cut across French and English. Immersion research has shown that even advanced learners continue to use these tenses indiscriminately.

For these reasons, Harley (1989) conducted an experimental study in Grade 6 French immersion classrooms to determine the effects of form-focused instruction on the use of these tenses. A set of form-focused instructional activities was 
Table I. Summary table of five quasi-experimental studies of form-focused instruction in French immersion classrooms

\begin{tabular}{|c|c|c|c|c|c|c|}
\hline & \multicolumn{4}{|c|}{ Design features } & \multirow{2}{*}{\multicolumn{2}{|c|}{$\begin{array}{l}\text { Significant improvement } \\
\text { (relative to Comparison groups without instruction) }\end{array}$}} \\
\hline & \multirow{2}{*}{$\begin{array}{l}\text { Age of } \\
\text { learners }\end{array}$} & \multirow{2}{*}{$\begin{array}{l}\text { Target } \\
\text { features }\end{array}$} & \multirow{2}{*}{$\begin{array}{l}\text { Length of } \\
\text { treatment }\end{array}$} & \multirow[b]{2}{*}{ Measures } & & \\
\hline & & & & & Immediate & Delayed \\
\hline $\begin{array}{l}\text { Harley } \\
(\text { I } 989)\end{array}$ & $\begin{array}{l}\text { I I-I } 2 \\
\text { (grade 6) }\end{array}$ & $\begin{array}{l}\text { passé composé } \\
\text { and imparfait }\end{array}$ & $\begin{array}{l}\text { I } 2 \text { hrs/ } \\
8 \text { weeks }\end{array}$ & $\begin{array}{l}\text { Written production } \\
\text { Cloze test } \\
\text { Oral production }\end{array}$ & $\begin{array}{l}\text { no } \\
\text { yes } \\
\text { yes }\end{array}$ & $\begin{array}{l}\text { no } \\
\text { no } \\
\text { no }\end{array}$ \\
\hline $\begin{array}{l}\text { Day/Shapson } \\
\text { (I99I) }\end{array}$ & $\begin{array}{l}\text { I2-I3 } \\
\text { (grade 7) }\end{array}$ & $\begin{array}{l}\text { conditional } \\
\text { mood }\end{array}$ & $\begin{array}{l}\text { I7 hrs/ } \\
6 \text { weeks }\end{array}$ & $\begin{array}{l}\text { Written production } \\
\text { Cloze test } \\
\text { Oral production }\end{array}$ & $\begin{array}{l}\text { yes } \\
\text { yes } \\
\text { no }\end{array}$ & $\begin{array}{l}\text { yes } \\
\text { yes } \\
\text { no }\end{array}$ \\
\hline $\begin{array}{l}\text { Lyster } \\
\text { (I994) }\end{array}$ & $\begin{array}{l}\text { I } 3-\mathrm{I} 4 \\
(\text { grade } 8)\end{array}$ & $\begin{array}{l}\text { second-person } \\
\text { pronouns }\end{array}$ & $\begin{array}{l}\text { I } 2 \text { hrs/ } \\
5 \text { weeks }\end{array}$ & $\begin{array}{l}\text { Written production } \\
\text { Multiple-choice test } \\
\text { Oral production }\end{array}$ & $\begin{array}{l}\text { yes } \\
\text { yes } \\
\text { yes }\end{array}$ & $\begin{array}{l}\text { yes } \\
\text { yes } \\
\text { yes }\end{array}$ \\
\hline $\begin{array}{l}\text { Harley } \\
(\text { I998) }\end{array}$ & $\begin{array}{l}7-8 \\
\text { (grade } 2)\end{array}$ & $\begin{array}{l}\text { grammatical } \\
\text { gender }\end{array}$ & $\begin{array}{l}8 \text { hrs/ } \\
5 \text { weeks }\end{array}$ & $\begin{array}{l}\text { Binary-choice test } \\
\text { Aural discrimination } \\
\text { Object identification } \\
\text { Picture description }\end{array}$ & $\begin{array}{l}\text { yes } \\
\text { yes } \\
\text { no } \\
\text { yes }\end{array}$ & $\begin{array}{l}\text { yes } \\
\text { yes } \\
\text { no } \\
\text { yes }\end{array}$ \\
\hline $\begin{array}{l}\text { Lyster } \\
(2004 \mathrm{~b})\end{array}$ & $\begin{array}{l}\text { IO-I I } \\
\text { (grade 5) }\end{array}$ & $\begin{array}{l}\text { grammatical } \\
\text { gender }\end{array}$ & $\begin{array}{l}9 \text { hrs/ } \\
5 \text { weeks }\end{array}$ & $\begin{array}{l}\text { Binary-choice test } \\
\text { Text completion } \\
\text { Object identification } \\
\text { Picture description }\end{array}$ & $\begin{array}{l}\text { recast and prompt groups } \\
\text { all treatment groups } \\
\text { prompt group } \\
\text { prompt group }\end{array}$ & $\begin{array}{l}\text { all treatment groups } \\
\text { prompt group } \\
\text { all treatment groups } \\
\text { all treatment groups }\end{array}$ \\
\hline
\end{tabular}


implemented in six experimental classrooms for approximately twelve hours during an eight-week period. The main activity was the creation of childhood albums, which required students to describe various childhood memories, both orally and in writing along with authentic photographs, depicting either specific and completed actions or ongoing and incomplete actions in the past. Other instructional activities involved reading the legend of Loup-garou, working in groups to create new legends and playing language games.

Pretests, immediate post tests, and delayed post tests were administered to the experimental group as well as to a comparison group to compare classes on three measures: a cloze test, a composition task and an oral interview. Immediate post test results revealed benefits on the cloze test and the oral interview for the experimental group, but no statistically significant differences between the experimental and comparison groups on the composition task. Three months later, on the delayed post test, no significant differences were found between the groups on any of the measures. Important to mention here is that students in the experimental group continued nonetheless to improve, but so did students in the comparison group. Harley explained that comparison teachers indicated on questionnaires that they too had devoted a considerable amount of time to the teaching of the passé composé and the imparfait. Furthermore, experimental teachers indicated that the treatment materials focused much more on content than on form, even though many students had not even mastered the formal aspects of the verb inflections.

\subsection{Conditional Mood}

Research has shown that immersion students are able to understand the hypothetical meaning of conditionals, but that this ability to comprehend is not matched by the ability to correctly produce conditionals (e.g., Harley and Swain, I984). Their lack of success may be attributed to at least three factors. First, the conditional in French is derivative and dependent on verbal inflections that are morphologically more complex than the English conditional, which consists of the modal verb would followed by a simple verb stem. A second factor is that learners can avoid the conditional and still express hypothetical meaning without causing much misunderstanding. When the need arises to express the notion of uncertain possibility in the future, learners who are unable to produce conditionals can resort to simpler means of expression, by opting for the futur simple or even the futur proche in conjunction with invariable adverbs such as probablement and peutetre to add modal value. A third factor is low frequency in the L2 classroom context. One observation study of several immersion classrooms (reported in Swain, I996) showed that conditional verb forms were rare in the natural talk of immersion teachers, comprising on average only about 3 per cent of all finite verbs used.

For these reasons, Day and Shapson (I99I) conducted a quasi-experimental study using six experimental and six comparison classes at the Grade 7 level (I2I3-year-old students) to test the effects of form-focused instruction on the use of 
the conditional. The thematic context involved the planning of an imaginary space colony and thus integrated concepts from the science class. Students were asked to play the role of ecologists to design a space station that would recreate a natural environment where space pioneers would be able to settle. The objective was to provide students with a context for using the conditional to express possible yet uncertain outcomes in the future. The instructional unit, which was implemented in the experimental classes for an average of seventeen hours during a six-week period, included the following activities:

- planning the space colony;

- presentation of an oral report describing and justifying the students' plan;

- making a model of the plan;

- preparation of a written report describing each part of the colony and its importance;

- preparation of a newspaper article describing what the life of the space pioneers would be like.

A cooperative-learning approach was adopted to maximise student interaction and to ensure the use of the conditional in communicative situations (for example, language monitors were appointed in each group to record each time the conditional was used). In addition, every lesson began with a language game or exercise that served as a reminder to students of the forms and functions of the conditional.

On immediate post test measures, the experimental group demonstrated significant gains on a cloze test and a written composition, but not in an oral interview, and then maintained these significant gains at the time of delayed post testing eleven weeks later. Day and Shapson attributed the relatively smaller gains in speaking to an apparent time-lag between internalisation of rule-based declarative knowledge and automatisation of that knowledge in speaking, caused by competition between newly acquired forms and more easily accessible interlanguage forms. In other words, it proved more difficult to alter automatised routines in speaking than in writing.

\section{$3 \cdot 3$ Second-Person Pronouns}

The development of an accurate system of second-person reference in French is not a straightforward process for young anglophone learners of French in early immersion classrooms (Swain and Lapkin, I990; Lyster and Rebuffot, 2002). This is due to a combination of factors, which together aptly illustrate the interaction of external and internal contributions to L2 development: that is, the interaction of features in the linguistic environment (i.e., classroom input) with a learner's own developing system of linguistic representations and cognitive processing (Long, I996).

In terms of the linguistic environment, Lyster and Rebuffot's (2002) discourse analysis of classroom input showed that, in addition to serving as a second-person 
pronoun of address to mark singular and familiar reference, $t u$ indicates indefinite reference and even plural reference in discourse contexts where a teacher's need to express intimacy or solidarity with young children competes with the need to express plurality. Although infrequent in the linguistic environment, a teacher's use of $t u$ forms with seemingly plural referents seems to provide sufficient positive evidence to young learners of French that $t u$ can serve as an all-encompassing second-person pronoun. In the absence of negative evidence, and although the all-encompassing function of $t u$ occurs only minimally in the input, young L2 learners are induced to over-generalise the functions of $t u$, because it corresponds precisely with their cognitive predisposition for selectively attending to only one second-person pronoun, equivalent to you. This kind of split, where a single form in the $\mathrm{L}_{\mathrm{I}}$ is manifest as two or more in the $\mathrm{L}_{2}$, is often considered to be a prime source of difficulty for L2 learners who, for the sake of economy, may adopt one form at the expense of the other. By far the most frequent of the two forms, as well as the one with simpler verb forms, $t u$ is the secondperson pronoun used almost exclusively by many immersion students (but see Dewaele, 2002, regarding adult learners of European French and their preference for vous). Interlanguage forms that develop as a result of both LI influence and ambiguous L2 input appear to be especially recalcitrant in homogeneous classrooms where L2 learners share the same Li (Lightbown, I992). Second-person pronouns in French are thus prime candidates for form-focused instruction in immersion classrooms.

Lyster (I994) conducted a classroom study at the Grade 8 level (with I3-I4year-old students) that aimed to measure the effect of form-focused instruction on French immersion students' sociolinguistic competence: that is, their ability to recognise and produce contextually appropriate language, including their use of second-person pronouns in formal and informal contexts. The instructional unit was implemented in three experimental classrooms for an average of twelve hours over five weeks and involved the following types of activities:

- explicit comparisons of various speech acts in formal and informal contexts;

- role plays with peer feedback in contexts contrived to be either formal or informal;

- structural exercises highlighting verb inflections;

- analysis of second-person pronouns in dialogues extracted from a novel;

- comparison of formal and informal letters and invitations;

- creation of formal and informal letters and invitations.

Tests included measures of oral production, written production and multiple choice, administered to the three experimental and two comparison classes immediately before and after the treatment, then again one month later. Results showed significant gains, both in the short- and long-term, in students' ability to use vous in formal contexts in both written and oral production tasks, and in their awareness of sociolinguistic appropriateness as demonstrated by their performance on multiple-choice tests. 


\subsection{Grammatical Gender}

Turning now to studies of grammatical gender, we can say that, even after many years of classroom exposure to French, immersion students, as well as many other learners of French L2, fail to master this grammatical sub-system. Grammatical gender markers are not salient in classroom discourse, in spite of their frequency; nor do they convey, in the case of inanimate nouns, any semantic distinctions. Moreover, grammatical gender does not exist in English. Carroll (I989) explains that native speakers of French acquire and process determiners and nouns as co-indexed chunks, whereas anglophone learners of French acquire and process determiners and nouns as distinct syntactic words and independent phonological units.

Anglophone learners of French are thus predisposed to learn lexical items separately from their gender attribution, and are encouraged to learn gender attribution on an item-by-item basis, because most French grammarians claim that grammatical gender is arbitrary and unsystematic in the case of inanimate nouns (e.g., Bérard and Lavenne, I99i; Jacob and Laurin, I994; Dubois and Lagane, I995; Grevisse and Goosse, I995; Bosquart, I998). Yet there exists considerable evidence, both corpus-based (e.g., Tucker, Lambert and Rigault, I977) and psycholinguistic (e.g., Karmiloff-Smith, I979), suggesting instead that gender attribution is largely rule-driven and based on word-internal structural properties. For example, based on analyses of nouns appearing in Le Petit Larousse, Tucker (I967: I3) concluded that 'gender does co-occur, in a systematic and predictable manner, with noun ending' (see also Stevens, I984: Surridge, I986; I995; Huot, I99I; Batchelor and Offord, I993). In a recent analysis of over I0,000 nouns in Le Robert Junior Illustré, organized according to some Ioo endings that are either reliably feminine, reliably masculine, or ambiguous, I found that 80 per cent of feminine nouns and 80 per cent of masculine nouns have endings that reliably predict their grammatical gender (Lyster, 2004a). Some predictors are primarily orthographic, showing up in the spelling of suffixes. For example, the suffix -elle is reliably feminine whereas the homophonous ending -el reliably predicts masculine gender. Other predictors are phonological, such as the reliably masculine ending /o/ and the reliably feminine ending / $\mathrm{et} /$, each with variable orthography: /o/ =-eau, -ot, -op; /عt/ =-aite, -ète, -ette. The prospect of providing young L2 learners with opportunities to induce rules to help them predict the grammatical gender of large groups of nouns with similar endings motivated two quasi-experimental studies investigating the extent to which form-focused instruction improves immersion students' ability to accurately assign grammatical gender.

Harley (I998) conducted a study in Grade 2 immersion classrooms with 78-year-old students, using form-focused activities designed to draw attention to primarily phonological clues in noun endings that reliably predict grammatical gender. The instructional treatment was designed to be implemented for twenty minutes a day over a five-week period. Each student created two illustrated dictionaries (one for masculine words and the other for feminine words) and 
labels were prominently displayed around the classrooms to identify the names of objects along with their grammatical gender clearly marked. In addition, the treatment incorporated a series of age-appropriate language games, including I Spy, Simon Says, Concentration, Bingo and My Aunt's Suitcase (see Harley, I998, for details), all of which were designed to provide learners with opportunities to practice associating grammatical gender with noun endings.

The study demonstrated that, relative to students in the six comparison classes, students from the six experimental classes made significant long-term progress as demonstrated by three of the four measures (two aural tasks and an oral picturedescription task). The only measure that did not reveal significant improvement was an oral task requiring students to identify the gender of low-frequency unfamiliar nouns, such as tondeuse, barbotte and sabot.

Building on Harley's (I998) study, I conducted a classroom study at a higher grade level with IO-I I-year-old students in Grade 5 (Lyster, 2004b). The formfocused instruction was implemented by three different teachers, each with two classes, for approximately 8-Io hours over five weeks in the context of subjectmatter instruction. The instructional unit was designed around the children's regular curriculum, and contained simplified versions of texts found in their commercially produced materials. These simplified texts provided the context for drawing students' attention to noun endings as predictors of grammatical gender. Typographical enhancement was used to highlight, in bold, the endings of target nouns embedded in these texts. As students read each text, they added missing definite or indefinite articles before each noun by checking its gender in the original text. Once these texts were completed, students classified target nouns according to their endings and gender attribution, and then identified the phonological or orthographic rules governing the patterns they observed. Some of these tasks revolved around the students' history program, while others pertained to their science program.

This study was designed to examine not only the overall effects of instruction, but also the effects of different types of feedback. In addition to the comparison group, then, there was not just one but three experimental groups, each receiving the same instructional unit, but each exposed to a different oral feedback option: either recasts, prompts, or no feedback. Recasts are defined as an implicit reformulation of the students' nontarget utterance, whereas prompts are feedback techniques that push learners to self-repair without providing them with the target form: for example, clarification requests (Pardon?) or repetition of error (Mon mère?). The form-focused instructional unit was thus implemented by the three experimental teachers in different ways that permitted comparisons of oral feedback options.

Four measures were administered immediately before and after the instructional unit and then again two months later, for a total of eight post tests. Results revealed that all three treatment groups demonstrated significant long-term improvement on all but one measure at the time of delayed post testing, but showed short-term improvement on this measure at the time of immediate post testing. Prompts proved to be the most effective type of feedback, with the prompt group distinguishing 
itself as the only group to significantly outperform the comparison group on all eight measures. The recast group significantly outperformed the comparison group on five of the eight measures, while the instruction-only group (receiving no feedback) significantly outperformed the comparison group on four of the eight measures. Form-focused instruction with recasts thus proved to be only marginally more effective than form-focused instruction without feedback.

\subsection{Summary}

To summarise (refer to Table I), the instructional treatment targeting the passé composé and imparfait yielded short-term improvement on two of the three measures, but no long-term significant improvement on any measures. Form-focused instruction on conditionals yielded short- and long-term significant improvement in written production, but none in oral production. In contrast, the other three studies generally yielded more positive results. Instruction on sociostylistic variation with emphasis on second-person pronouns yielded short- and long-term improvement on all measures. The instructional treatment targeting grammatical gender in Grade 2 resulted in significant short- and long-term improvement for learners on three of the four measures; an oral task that required participants to assign grammatical gender to unfamiliar nouns yielded no significant results (but learners in the Grade 5 study did improve significantly in their performance on a similar task, suggesting that older learners are more predisposed to induce rules and also benefit from access to a much larger set of stored vocabulary items). Instruction on grammatical gender with older learners in Grade 5 yielded significant long-term improvement for all groups exposed to form-focused instruction on three of the four measures; the one measure not showing significant long-term improvement for all treatment groups nonetheless showed significant improvement for the three treatment groups at the time of immediate post testing; two months later, the group receiving feedback in the form of prompts distinguished itself by being the only group to significantly outperform the comparison group on this measure. The next section aims to explain these and other findings by comparing instructional options across the five studies.

\section{DISCUSSION}

The aim of this section is to explore the theoretical and practical repercussions of the five quasi-experimental classroom studies reviewed in the previous section. The five studies share the context of French immersion as well as many sine qua non features of quasi-experimental designs. These shared features allow us to make comparisons across these studies and to draw conclusions about effective formfocused instructional options in similar types of contexts. I acknowledge, however, that a multitude of factors, well beyond instructional variables, can affect learning outcomes in classroom intervention studies. For example, in both the Harley (I989) study and the Day and Shapson (I99I) study, comparison teachers reported that 
they too were teaching the target forms. In both studies, learners exposed to the experimental treatment did in fact continue to progress throughout the study, but the significant effects were neutralised by improvement made by students in comparison classes. This was not the case in studies of grammatical gender and second-person pronouns.

It can also be argued that differences in learner outcomes are due primarily to the linguistic nature of the target features. For example, the functional distinctions expressed by the passé composé and imparfait, as well as the hypothetical meanings expressed by the conditional mood, are arguably much more complex than the ostensibly binary distinctions apparent in grammatical gender and second-person pronouns. To level the playing field for the sake of comparing these studies, I argue instead that grammatical gender also constitutes a relatively complex subsystem, which is not simply binary in nature when one factors into the equation approximately Ioo noun endings as well as the multiple effects that grammatical gender has on morphosyntax within and across sentences. Even the learning of second-person pronouns in French does not entail simple binary choices when we consider: first, the complexity of social variables that need to be taken into account; second, the use of $t u$ to mark indefinite and seemingly plural reference; and third, the effects of pronoun choice on morphosyntax, again within and across sentences.

To provide a basis for comparing instructional options in theoretical terms, I will draw on elements from cognitive theory and, in particular, Skehan's (I998) information-processing model, which identifies as a key factor in interlanguage development the learner's conscious awareness of rule-based representations. In his model, noticing plays a central role in converting input to intake during input processing (see also Schmidt, I990), and is triggered by input qualities such as frequency and salience and by input features that have been contrived for instructional purposes (e.g., typographical enhancement). Intake reaches a central processing mechanism that operates a dual-mode system composed of two interrelated representational systems: an analytic rule-based system and a memory-driven exemplar-based system (see also Murphy, 2000). Output processing then engages the learner's memory capacity differentially through retrieval from the dual-mode system, leading either to computed rule-based performance or memory-driven exemplar-based performance. Skehan argues that, during online communication, communicative pressure and the need for fast access will make the exemplar-based system the system of choice, thus reducing the likelihood that the compact storage and powerful generative rules of the rule-based system will be accessed to compute well-formed utterances. While the exemplar-based system is especially useful for spontaneous oral production in interactional contexts, because its units can be accessed with minimal computational demands, Skehan contends that interlanguage change is more effectively activated through the rule-based system and that conscious awareness predisposes learners towards such a rule-based perspective (see also Schmidt, I990).

In pedagogical terms, therefore, controlled practice activities that engage learners' awareness of rule-based representations are useful for circumventing their 


$\underset{\text { Noticing activities }}{\stackrel{\text { receptive mode }}{\longleftarrow} \quad \text { Awareness activities } \leftrightarrow \quad \text { Productive mode }} \longrightarrow$

Figure I. Form-focused instructional options.

over-reliance on communication strategies and thereby effecting change in the interlanguage (Ranta and Lyster, 2004). Conversely, during communicative practice activities that engage learners in more meaningful and motivating tasks, lexicalised exemplar-based representations will be retrieved more readily, enabling spontaneous production but not engaging learners' language awareness to the same extent, thereby reducing the potential for changes to the interlanguage system.

To compare the effectiveness of form-focused instructional options across the five intervention studies, I draw on elements from cognitive theory to characterise formfocused instruction as instruction that emphasises, on the one hand, noticing and language awareness to enable learners to restructure interlanguage representations, and on the other, opportunities for practice that allow learners to proceduralise more target-like representations. We can best view noticing, language awareness and practice as form-focused instructional options along a continuum, as depicted in Figure I. Learners engage primarily in a receptive mode during noticing activities and in a productive mode in practice activities. Activities designed to develop language awareness engage learners either receptively or productively, or both. I propose that, considered chronologically, the five studies reveal a progression in how form-focused instruction has been conceptualised over the past fifteen years, with later studies owing their more robust findings to specific aspects of the instructional treatments: namely, a more balanced distribution of opportunities for noticing, awareness and practice.

I begin with Harley's study on the functions of the passé composé and imparfait. One of the main objectives of the instructional unit was to provide, according to Harley (1989: 335), 'more opportunities for students to express these functions in the realisation of interesting, motivating tasks.' The main communicative activity involved the creation of childhood albums. This activity was indeed interesting and motivating, so much so that Harley reported that teachers and students alike seemed to overlook the linguistic focus. Overall, the instructional treatment may have overemphasised production activities at the expense of more activities promoting noticing and language awareness. In fact, it was found in the end that, not only did students have difficulty distinguishing the functional distinctions of these two tenses, they had not mastered their formal characteristics either. In cases like these, more meaningful content-based interaction may not be what immersion students need to be pushed in their interlanguage development.

Similarly, Day and Shapson (I99I) described the principles on which their instructional treatment was based as follows:

- integration of second-language teaching and content teaching;

- classroom interaction characterised by negotiation of meaning;

- curriculum study that is intrinsically motivating. 
I would argue that in both the Harley and Day and Shapson studies the emphasis on negotiation of meaning, along with intrinsically motivating content teaching, is unlikely to have pushed students to notice and to use the target verb forms more accurately. Recent classroom observation studies (e.g., Lyster and Ranta, I997; Lyster, I998; 2002) have shown that meaningful interaction related to content is typical of immersion classroom discourse. Therefore, the main thematic activities in the Harley and Day and Shapson studies may not have created contexts that were sufficiently different from other immersion activities. By focusing students on meaningful interaction and motivating content, the instructional units may have fallen short of drawing learners' attention to linguistic accuracy any more than is typically the case.

The results of the Day and Shapson study were more enduring than those of Harley, as students made significant progress on the cloze test and composition, but not on the oral production test. Day and Shapson reported having observed a tendency during the instructional activities for students to contextualise their speech in the present, thus eliminating the need to use the conditional to express hypothetical meaning and thereby decreasing opportunities to practise using conditionals in a meaningful context. As in the Harley (I989) study, therefore, the focus on form during the oral activities was superseded by more spontaneous expression and the use of simplified forms.

Furthermore, in the case of the study on conditionals, I would suggest that the task demands did not really create an obligatory context for expressing hypothetical meaning. Learners negotiated their plans for a space colony during face-to-face interaction and then literally designed a model of the colony, thereby situating the task in the here-and-now. In other words, there was nothing hypothetical about the plan, because students actually designed it. What was hypothetical was whether or not the plan would be selected as the winning design that would be (hypothetically, at least) put into operation. Thus, although the tasks were pedagogically designed to encourage the use of conditionals, they arguably lacked linguistic constraints, in terms of pragmatic appropriateness and discourse coherence, requiring students to use conditionals to complete the tasks.

Activities engaging learners in noticing, language awareness and practice were unevenly distributed throughout the instructional units in these two studies. Activities promoting noticing and language awareness appear to have had less emphasis than production activities and, furthermore, the production activities emphasised communicative meaning-based practice much more than controlled practice. Because activities promoting noticing, language awareness and controlled practice were more apparent in the study on second-person pronouns and in both studies on grammatical gender, I would argue that more opportunities for noticing and language awareness, in addition to controlled automaticity practice and provision of feedback, might have been more effective at helping learners in the Harley (I989) and Day and Shapson (I99I) studies to restructure interlanguage representations and proceduralise more target-like uses of tense and aspect. 
In Lyster (I994), for example, noticing activities required students to classify utterances as either formal or informal; awareness tasks then required them to contrast the language features that are characteristic of either formal or informal utterances; and controlled practice activities with peer feedback engaged students in various role plays (e.g., asking for and giving directions) in which they alternately addressed either a friend or an adult stranger. In Harley (I998), noticing activities required students to attend to the co-occurrence of nouns with gender-specific articles on identification labels displayed around the classroom; awareness activities required students to each create their own gender-specific dictionaries, one for masculine and other for feminine entries; and controlled practice activities required students to recall and associate nouns with similar endings in games such as 'Concentration' and to associate gender-specific articles with target nouns in various games such as 'Bingo' (to win, students had to name all objects in their winning row, accurately using gender-specific articles) and 'La valise de ma tante' (to play, students had to name various objects with similar endings and correctly assign grammatical gender). In Lyster (2004b), noticing activities required students to read curriculumrelated texts in which endings of target nouns were made to appear salient by means of typographical enhancement; awareness activities then required students to group nouns with similar endings together and determine which gender their endings predict; and controlled practice activities required students to accurately assign gender-specific articles to target nouns in curriculum-related materials and language games involving crossword puzzles, rhymes and riddles.

\section{CONCLUSION}

In conclusion, analysis of instructional options in relation to learning outcomes in the five classroom intervention studies suggests that effective form-focused instruction in immersion contexts incorporates a balanced distribution of activities interweaving opportunities for noticing, language awareness and practice.

Noticing activities serve as effective catalysts for drawing learners' attention to problematic target features that have been contrived to appear more salient and/or frequent in oral and written input (for example, by means of typographical enhancement). Their aim is to effect change towards more target-like declarative representations of the L2. Awareness activities, which include inductive rulediscovery tasks and opportunities to compare and contrast language patterns, followed by different types of metalinguistic information, generally serve to consolidate the restructuring of rule-based declarative representations. Practice activities provide learners with important opportunities to proceduralise their declarative knowledge of emerging target-like forms, in a variety of pedagogical contexts ranging from meaningful collaborative tasks at the communicative end of the spectrum of practice activities, to linguistic games and role plays at the other end. However, the comparative analysis suggests that, in cases where the areas of linguistic difficulty are well-known sources of persistent errors, communicative 
practice involving lots of negotiation of meaning is less effective than controlled practice, which allows for more systematic provision of feedback.

These observations find support in Skehan's (I998) claim that instructional activities that serve primarily to induce learners to rely on communication strategies may lead them to bypass target forms and instead to use unanalysed nontarget representations that are more accessible. He puts into question the role of negotiation of meaning insofar as it aims to achieve mutual comprehensibility, at the expense of moving L2 development forward in terms of formal accuracy and complexity. I hasten to add that there is little doubt that opportunities for more open-ended communicative practice and negotiation of meaning contribute to other aspects of L2 development. For example, Harley (I993) suggested that the experiential approach underlying content-based instruction allows young learners to internalise key aspects of the target system, such as phonologically salient and high-frequency lexical items, as well as syntactic patterns that are congruent with the LI. It is indeed important to stress that the form-focused instructional options identified here as effective are complemented in the immersion context by its communicatively rich backdrop of subject-matter instruction. Whether or not the same instructional options would prove to be as effective in more typical L2 instructional contexts, where opportunities for sustained exposure and authentic communication are limited by time constraints and lack of focus on content other than the target language itself, cannot be addressed by the foregoing comparative analysis, given its exclusive concern for immersion contexts, and thus remains an open question for further consideration.

Given the instructional and interactional design of immersion pedagogy (see Genesee, I99I; Met, I994; Lyster, 2002), learners in immersion classrooms benefit from years of exposure to target input and ample opportunities for authentic communication involving negotiation of meaning, which facilitates comprehension and also provides supportive scaffolding when target forms are beyond learners' current production abilities. As a result of these opportunities, immersion students develop high levels of strategic communicative ability, but their interlanguage appears to reach a developmental plateau in terms of accuracy. Continued reliance on communication strategies and negotiation of message comprehensibility arguably loses its effectiveness, over time, for promoting continued language growth in the immersion classroom context. To drive their interlanguage development forward, therefore, these learners need to be pushed to access target forms that are in competition with more readily accessible and recalcitrant interlanguage forms (Ranta and Lyster, 2004). Supported empirically by the studies reviewed here, cognitive theory predicts the feasibility of pushing interlanguage development above and beyond the plateau by means of formfocused instructional options that include noticing and language awareness activities designed to effect change towards more target-like declarative representations, and practice activities designed in tandem with strategic opportunities for feedback to enable learners to proceduralise their knowledge of emerging target forms. 
Author's address:

Roy Lyster

Department of Integrated Studies in Education

McGill University

3700 McTavish Street

Montreal, QC

Canada $\mathrm{H}_{3} \mathrm{~A}_{1} \mathrm{Y}_{2}$

e-mail:roy.lyster@mcgill.ca

\section{REFERENCES}

Anderson, J. (1983). The architecture of cognition. Cambridge, MA: Harvard University Press.

Anderson, J. (1985). Cognitive psychology and its implications. New York: Freeman.

Anderson, J., Corbett, A., Koedinger, K. and Pelletier, R. (I995). Cognitive tutors: lessons learned. The Journal of Learning Sciences, 4: 167-207.

Aston, G. (I986). Trouble-shooting in interaction with learners: The more the merrier? Applied Linguistics, 7: I28-I43.

Batchelor, R. and Offord, M. (1993). Using French: a guide to contemporary usage. Cambridge: Cambridge University Press.

Bérard, E. and Lavenne, C. (I99I). Grammaire utile du français, Paris: Hatier.

Bosquart, M. (1998). Nouvelle grammaire. Montreal, QC: Guérin.

Braidi, S. (1995). Reconsidering the role of interaction and input in second language acquisition. Language Learning, 45: I4 I-I75.

Carroll, S. (1989). Second-language acquisition and the computational paradigm. Language Learning, 39: 535-594.

Carroll, S. (1999). Input and SLA: Adults' sensitivity to different sorts of cues to French gender. Language Learning, 49: 37-92.

Day, E. and Shapson, S. (I99I). Integrating formal and functional approaches to language teaching in French immersion: An experimental study. Language Learning, 4I: $25-58$.

de Bot, K. (1996). The psycholinguistics of the output hypothesis. Language Learning, 46: 529-555.

DeKeyser, R. (1998). Beyond focus on form: Cognitive perspectives on learning and practicing second language grammar. In: C. Doughty and J. Williams (eds), Focus on form in classroom second language acquisition. Cambridge: Cambridge University Press, pp. $42-63$.

DeKeyser, R. (200I). Automaticity and automatization. In: P. Robinson (ed.), Cognition and second language instruction. Cambridge: Cambridge University Press, pp. I25-I5I.

Dewaele, J.-M. (2002). Variation, chaos et système en interlangue française. Acquisition et Interaction en Langue Étrangère, I7: I43-I67.

Doughty, C. and Williams, J. (I998). Pedagogical choices in focus on form. In: C. Doughty and J. Williams (eds), Focus on form in classroom second language acquisition.

Cambridge: Cambridge University Press, pp. I97-26r.

Dubois, J. and Lagane, R. (I995). Grammaire. Paris: Larousse. 
Ellis, R. (200I). Investigating form-focused instruction. Language Learning, 5I (Suppl. I): $\mathrm{I}-46$.

Ellis, R. (2002). The place of grammar instruction in the second/foreign curriculum. In: E. Hinkel and S. Fotos (eds), New perspectives on grammar teaching in second language classrooms. Mahway, NJ: Lawrence Erlbaum, pp. I7-34.

Foster, P. (1998). A classroom perspective on the negotiation of meaning. Applied Linguistics, I9: I-23.

Genesee, F. (I99I). Second language learning in school settings: Lessons from immersion. In: A. Reynolds (ed.), Bilingualism, multiculturalism, and second language learning. Hillsdale, NJ: Lawrence Erlbaum, pp. I83-202.

Grevisse, M. and Goosse, A. (1995). Nouvelle grammaire française. Louvain-la-Neuve: Duculot.

Harley, B. (1989). Functional grammar in French immersion: A classroom experiment. Applied Linguistics, Iо: 33 I-359.

Harley, B. (1993). Instructional strategies and SLA in early French immersion. Studies in Second Language Acquisition, I 5: 245-259.

Harley, B. (I998) The role of form-focused tasks in promoting child L2 acquisition In: C. Doughty and J. Williams (eds), Focus on form in classroom second language acquisition. Cambridge: Cambridge University Press, pp. I56-I74.

Harley, B., Cummins, J., Swain, M. and Allen, P. (I990). The nature of language proficiency. In: B. Harley, P. Allen, J. Cummins and M. Swain (eds), The development of second language proficiency. Cambridge: Cambridge University Press, pp. 7-25.

Harley, B. and Swain, M. (I984). The interlanguage of immersion students and its implications for second language teaching. In: A. Davies, C. Criper and A. Howatt (eds), Interlanguage. Edinburgh: Edinburgh University Press, pp. 29I-3 I I.

Hulstijn, J. (I990). A comparison between the information-processing and the analysis/control approaches to language learning. Applied Linguistics, I I: 30-45.

Huot, C. (I99I). Dictionnaire des genres. Montreal, QC: Éditions du Méridien.

Jacob, R. and Laurin, J. (I994). Ma grammaire. Montreal, QC: Les Éditions françaises.

Johnson, K. (I996). Language teaching and skill learning. Oxford: Blackwell.

Karmiloff-Smith, A. (1979). A functional approach to child language. Cambridge: Cambridge University Press.

Kleifgen, J. and Saville-Troike, M. (I992). Achieving coherence in multilingual interaction. Discourse Processes, I5: i 83-206.

Krashen, S. (1994). The input hypothesis and its rivals. In: N. Ellis (ed.), Implicit and explicit learning of languages. London: Academic Press, pp. 45-77.

Lightbown, P. (I992). Can they do it themselves? A comprehension-based ESL course for young children. In: R. Courchêne, J. Glidden, J. St. John and C. Thérien (eds), Comprehension-based second language teaching. Ottawa: University of Ottawa Press, pp. $353-370$.

Lightbown, P. (1998). The importance of timing in focus on form. In: C. Doughty and J. Williams (eds), Focus on form in classroom second language acquisition. Cambridge: Cambridge University Press, pp. I77-I96.

Lightbown, P. and Spada, N. (1999). How languages are learned, 2nd edn. Oxford: Oxford University Press.

Long, M. (I996). The role of the linguistic environment in second language acquisition. In: W. C. Ritchie and T. K. Bhatia (eds), Handbook of language acquisition, vol. 2: second language acquisition. New York: Academic Press, pp. 4I3-468. 
Long, M. and Robinson, P. (I998). Focus on form: Theory, research, and practice. In: C. Doughty and J. Williams (eds), Focus on form in classroom second language acquisition. New York: Cambridge University Press, pp. I 5-4I.

Lyster, R. (1994). The effect of functional-analytic teaching on aspects of French immersion students' sociolinguistic competence. Applied Linguistics, I 5: 263-287.

Lyster, R. (1998). Recasts, repetition, and ambiguity in L2 classroom discourse. Studies in Second Language Acquisition, 20: 55-85.

Lyster, R. (I999). Immersion. In: B. Spolsky (ed.), Concise encyclopaedia of educational linguistics. Oxford: Pergamon, pp. 626-632.

Lyster, R. (2002). Negotiation in immersion teacher-student interaction. International Journal of Educational Research, 37: 237-253.

Lyster, R. (2004a, May). How to predict the grammatical gender of 8000 French nouns. Paper presented at the meeting of the American Association for Applied Linguistics, Portland, OR.

Lyster, R. (2004b). Differential effects of prompts and recasts in form-focused instruction. Studies in Second Language Acquisition, 26: 399-432.

Lyster, R. and Ranta, L. (1997). Corrective feedback and learner uptake: Negotiation of form in communicative classrooms. Studies in Second Language Acquisition, I9: 37-66.

Lyster, R. and Rebuffot, J. (2002). Acquisition des pronoms d'allocution en classe de français immersif. Acquisition et Interaction en Langue Étrangère, I7: 5I-7I.

McLaughlin, B. (I987) Theories of second language learning. London: Edward Arnold.

McLaughlin, B. (1990). Restructuring. Applied Linguistics, I I: I I 3-I 28.

Met, M. (I994). Teaching content through a second language. In: F. Genesee (ed.), Educating second language children. Cambridge: Cambridge University Press, pp. I 59I 82 .

Murphy, V. (2000). Compounding and the representation of L2 inflectional morphology. Language Learning, 50: I 53-197.

Norris, J. and Ortega, L. (2000). Effectiveness of L2 instruction: A research synthesis and quantitative meta-analysis. Language Learning, 50: 4I7-528.

O’Malley, M. and Chamot, A. (1990). Learning strategies in second language acquisition. Cambridge: Cambridge University Press.

Pica, T. (I994). Research on negotiation: What does it reveal about second-language learning conditions, processes, and outcomes? Language Learning, 44: 493-527.

Pica, T., Young, R. and Doughty, C. (1987). The impact of interaction on comprehension. TESOL Quarterly, 21: 737-758.

Ranta, L. and Lyster, R. (2004). A cognitive approach to improving immersion students' oral language abilities: The Awareness-Practice-Feedback sequence. Unpublished manuscript. Edmonton: University of Alberta.

Rebuffot, J. (I993). Le point sur l'immersion au Canada. Montreal, QC: Éditions CEC.

Schmidt, R. (I990). The role of consciousness in second language learning. Applied Linguistics, II: I29-I58.

Segalowitz, N. (I997). Individual differences in second language acquisition. In: A. de Groot and J. Kroll (eds), Tutorials in bilingualism: psycholinguistic perspectives. Mahwah, NJ: Lawrence Erlbaum, pp. 85-I 2 .

Shiffrin, R. and Schneider, W. (1977). Controlled and automatic human information processing: Perceptual learning, automatic, attending and a general theory. Psychological Review, 84: 127-190. 
Skehan, P. (1998). A cognitive approach to language learning. Oxford: Oxford University Press.

Spada, N. (1997). Form-focused instruction and second language acquisition: A review of classroom and laboratory research. Language Teaching, 30: 73-87.

Stevens, F. (1984). Strategies for second language acquisition. Montreal, QC: Eden.

Surridge, M. (1986). Genre grammatical et dérivation lexicale en français. Canadian Journal of Linguistics / Revue canadienne de linguistique, 3 I: 267-283.

Surridge, M. (1995). Le ou la? The gender of French nouns. Clevedon, UK: Multilingual Matters.

Swain, M. (1985). Communicative competence: some roles of comprehensible input and comprehensible output in its development In: S. Gass and C. Madden (eds), Input in second language acquisition. Rowley, MA: Newbury House, pp. 235-253.

Swain, M. (I988). Manipulating and complementing content teaching to maximize second language learning. TESL Canada Journal, 6: 68-83.

Swain, M. (1996). Integrating language and content in immersion classrooms: research perspectives. The Canadian Modern Language Review, 52: 529-548.

Swain, M. (1997). French immersion programs in Canada. In: J. Cummins and D. Corson (eds), Encyclopaedia of language and education, vol. 5: bilingual education. Amsterdam: Kluwer Academic Publishers, pp. 260-269.

Swain, M. and Lapkin, S. (I990). Aspects of the sociolinguistic performance of early and late French immersion students. In: R. Scarcella, E. Andersen and S. Krashen (eds), Developing communicative competence in a second language. New York: Newbury House, pp. 4I-54.

Towell, R. and Hawkins, R. (I994). Approaches to second language acquisition. Clevedon, UK: Multilingual Matters.

Tucker, R. (1967). The French Speaker's Skill with Grammatical Gender: An Example of Rulegoverned Behaviour. Unpublished doctoral dissertation, McGill University, Montreal, QC.

Tucker, R., Lambert, W. and Rigault, A. (I977). The French speaker's skill with grammatical gender: an example of rule-governed behaviour. Paris: Mouton. 